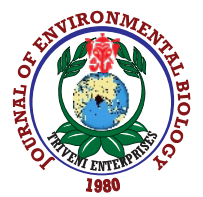

\title{
Biosorption of chromium ions through modified Eichhornia crassipes biomass form the aqueous medium
}

\author{
E. Parameswari ${ }^{1 *}$, R.P. Premalatha ${ }^{2}$, V. Davamani', P. Kalaiselvi', S. Paul Sebastian ${ }^{1}$ and K. Suganya ${ }^{1}$ \\ 'Department of Environmental Sciences, Tamil Nadu Agricultural University, Coimbatore - 641 003, India \\ ${ }^{2}$ Department of Soil science Agricultural Chemistry, Tamil Nadu Agricultural University, Coimbatore - 641 003, India \\ *Corresponding Author Email : parameswariphd@gmail.com
}

\section{Abstract}

Aim: To explore the potential of water hyacinth biomass as a low cost adsorbent for sequestrating chromium ions from aqueous solution.

Methodology: The biosorption behavior of chromium ions $(\mathrm{Cr}(\mathrm{III})$ and $\mathrm{Cr}(\mathrm{VI}))$ from aqueous solution by powdered water hyacinth biomass was assessed through series of batch experiments using advanced instrumentation techniques like Scanning Electron Microscopy with Energy Dispersive Xray analysis and Fourier Transform Infra-Red spectroscopy, pH zero point charge. The equilibrium relationship between sorbent and sorbate was determined in solution by using the isotherms Langmuir, Freundlich and Temkin models.

Results: The optimum $\mathrm{pH}$ for $\mathrm{Cr}(\mathrm{III})$ and $\mathrm{Cr}(\mathrm{VI})$ adsorption was 5.0 and 2.0 whereas the maximum $\mathrm{Cr}(\mathrm{III})$ and $\mathrm{Cr}(\mathrm{VI})$ adsorption was 99.80 and $89.15 \%$, respectively. Langmuir isotherm fitted the data well with $R^{2}$ value of 0.999

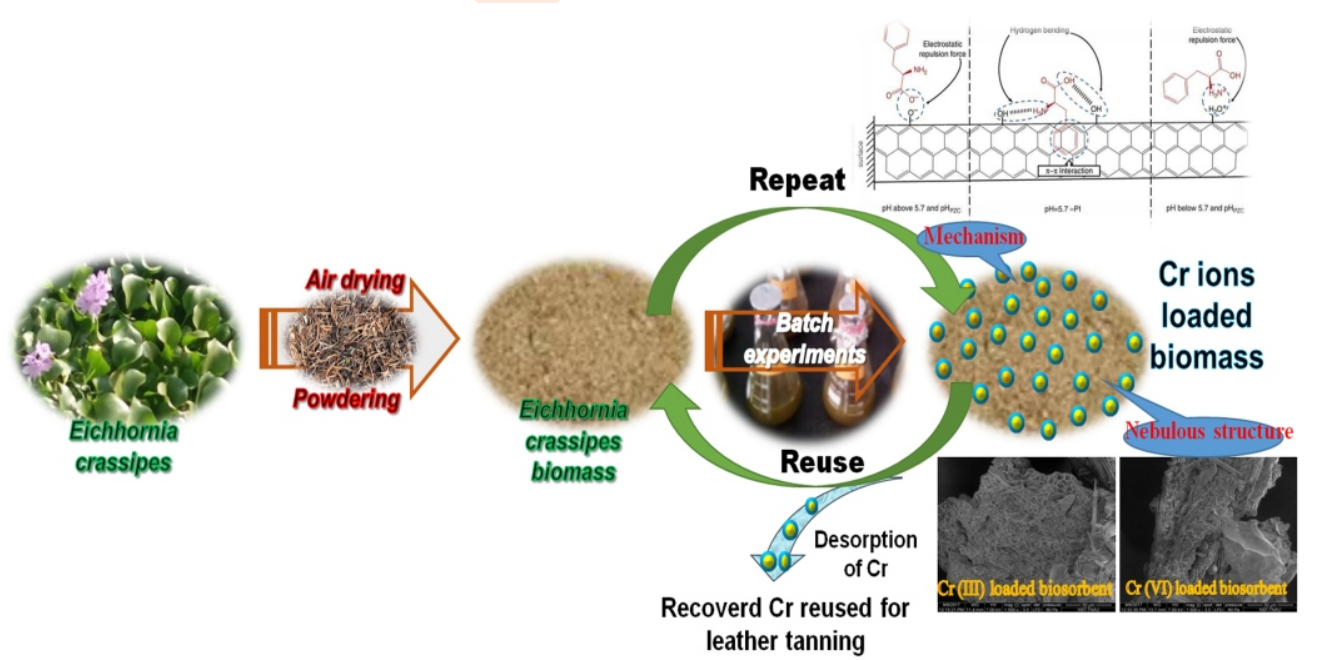
for both $\mathrm{Cr}(\mathrm{III})$ and $\mathrm{Cr}(\mathrm{VI})$ by the biosorbent. Adsorption kinetics showed that the experimental data fitted the pseudo second order kinetic model with $\mathrm{R}^{2}$ value of $0.999 \mathrm{for}$ both $\mathrm{Cr}$ (III) and $\mathrm{Cr}(\mathrm{VI})$. The EDX spectra peaks of $\mathrm{Ca}, \mathrm{O}, \mathrm{C}$ indicated the presence of functional groups such as $-\mathrm{OH}$ and $-\mathrm{COOH}$ in the biosorbent. The zeta potential analysis depicted that water hyacinth biomass had negative surface charge of (-) $23.5 \mathrm{mV}$.

Interpretation: Water hyacinth based biosorbent can be utilized for the removal of $\mathrm{Cr}$ ions from industrial waste water. Further, water hyacinth has additional advantage that it reduces or even eliminates the diverse impact of weeds on the environment.

Key words: Biosorption, Chromium removal, Water hyacinth

How to cite : Parameswari, E., R.P. Premalatha, V. Davamani, P. Kalaiselvi, S. Paul Sebastian and K. Suganya: Biosorption of chromium ions through modified Eichhornia crassipes biomass form the aqueous medium. J. Environ. Biol., 42, 62-73 (2021). 


\section{Introduction}

Heavy metal pollution is a serious threat to the aquatic environment. Heavy metals also known as trace metals are the most persistent and non-biodegradable pollutants discharged from various industries (Akpor et al., 2014).Chromium is a heavy metal that exists in several oxidation states, but the most stable and common forms are trivalent $\mathrm{Cr}(\mathrm{III})$ and hexavalent $\mathrm{Cr}(\mathrm{VI})$ species. Chromium in oxidation state $+6(\mathrm{Cr}(\mathrm{VI}))$ is very harmful, even the quantum intake is abysmally low whereas intake of $\mathrm{Cr}$ (III) in moderate amount is considered essential for human formaintaining the glucose level in the blood (Rajeshwari and Sailaja, 2014). The major anthropogenic sources of $\mathrm{Cr}$ are from a wide spectrum of industrial processes like alloying, plating, tanning of hides, refractory, metallurgy, paint, textile dyes, chemical and petroleum refinement industries (Avudainayagam et al., 2003). Tannery industry is considered as one of the most polluting industry. They are the major contributors of chromium pollution in the environment. Tanning industries have mushroomed in India for last several years. Almost $50 \%$ of these industries exist in Tamil Nadu. A total number of 2,161 tanneries are located in India and approximately 2000-3000 tonnes of chromium escapes into the environment annually from the industries.

The minimum effluent produced during leather processing is 2500 to $5000 \mid 100 \mathrm{~kg}^{-1}$ of hide. For every 100 kilogram of skin tanned, 3200 I of freshwater is required (Murali and Rajan, 2012). Unfortunately, a part of chromium salt alone reacts with skin during tanning process. The remaining quantity is retained in the tanning exhaust bath. During this process it releases enormous quantity of $\mathrm{Cr}$ rich effluent $\left(100\right.$ to $\left.300 \mathrm{mg} \mathrm{l}^{-1}\right)$. The permissible limit of $\mathrm{Cr}(\mathrm{VI})$ in the industrial effluent is $0.05 \mathrm{mgl}$ ${ }^{1}$ as per the guidelines of World Health Organization, whereas the maximum permissible limit for total $\mathrm{Cr}$ is $0.05 \mathrm{mg} \mathrm{l}^{-1}$ in drinking water. Among various industrial sources, leather tanning industry needs a relook as $40 \%$ of total $\mathrm{Cr}$ used in leather processing is retained in sludge (Kamaludeen et al., 2003). Disposal of these compounds on land and in water is inevitable, thereby increasing pressure on the environment.

The disastrous effect of $\mathrm{Cr}$ dates back to 1890 when the elevated risk of cancer was reported among the workers of chrome dye company (Newmann, 1890). Adding this, during the second world war the aircraft workers suffered from chromate induced dermatitis. To protect the environment and living organisms from the hazardous effect of $\mathrm{Cr}$, it is essential to remove $\mathrm{Cr}$ from wastewater. Conventional methods including membrane filtration, chemical precipitation, reduction, ion exchange, chelation, reverse osmosis and electrodialysis are available for its removal (Khatoon et al., 2013). Nevertheless, these technologies exhibit high energy requirements and generates toxic sludge which calls for economically sound, ecologically safe technology for $\mathrm{Cr}$ management. In this context, biosorption received attention. Biosorption is a biochemical process where biomass binds to the contaminant on its cellular level by various mechanisms like adsorption, absorption, precipitation, surface complexation and ion exchange (Fomina and Gadd, 2014). Biosorption of pollutants mainly nutrients and heavy metals in the water by dried plant based biomass or biomass derived carbon material are being widely utilized. In India, water hyacinth (Eichhornia crassipes) has been reported to remove $99.5 \%$ of $\mathrm{Cr}(\mathrm{VI})$ from the processed water of Sukinda chromite mines area, Orissa (Saha et al., 2017). Dubey (2014) investigated the biomass derived from Portulaca species used for adsorption of cadmium ions from contaminated water and achieved the sorption capacity upto $72 \%$ with the standardization of all the parameters for adsorption. Bioremediation of Cd (II), Mn (II), Cu (II), Zn (II) and $\mathrm{Pb}(\mathrm{II})$ by Potamogeton malaianus and $P$. pectinatus recorded $92 \%$ the absorption effectiveness (Peng et al., 2008).

The current study focus on removal of chromium ions by utilizing water hyacinth biomass as an adsorbent. Water hyacinth (Eichhornia crassipes) is the world's most important paramount noxious aquatic plant covering lakes, ponds, streams, ditches and backwater areas (Ghosh, 2010). This dreaded weed poses a serious challenge to aquatic inhabitants and is often blamed for choking water bodies. Under favorable conditions water hyacinth can grow up to 17.5 metric tons of wet biomass ha-1 day. Normal yield of water hyacinth is reported to be 150 MT fodder ha $^{-1}$ year in India (Malik, 2007; Sebastian et al., 2009). Availability in larger quantities, presence of many polyfunctional metal binding sites for both cationic and anionic metal complexes, high biosorption capacity, renewability and low cost makes water hyacinth a biosorbent for suitable sequestration of chromium species in aqueous solution.

\section{Materials and Methods}

Sample collection and preservation: Water hyacinth plants collected from Vaigai dam, located in Theni district of Tamil Nadu, India $\left(10^{\circ} 03^{\prime} 12^{\prime \prime} \mathrm{N} 77^{\circ} 35^{\prime} 23^{\prime \prime} \mathrm{E}\right)$ were washed to remove the sediments and other small floating fresh water aquatic weeds, dried, grounded and sieved through $0.2 \mathrm{~mm}$ sieve for further analysis.

Adsorbate: The stock solutionsof $\mathrm{Cr}(\mathrm{III})$ and $\mathrm{Cr}(\mathrm{VI})$ was prepared by using analytical grade $\mathrm{Cr}_{2}\left(\mathrm{SO}_{4}\right)_{3}$ and $\mathrm{K}_{2} \mathrm{Cr}_{2} \mathrm{O}_{7}$, in $1000 \mathrm{ml}$ of double distilled water. Appropriate dilution of the above stock was done to obtain the standards of required concentration. The $\mathrm{pH}$ of metal solution was adjusted with $1.0 \mathrm{~N} \mathrm{NaOH}$ or $1.0 \mathrm{NHCl}$.

Characterization of biosorbent: The structural orientation of biosorbent was analyzed with scanning electron microscopy (M/s. FEl- Quanta 20, Czech Republic) at 7.00 kV equipped with back scattered electron detector. Energy dispersive spectroscopy was used to analyze the elemental constituents of biosorbent sample. The functional groups present in the biosorbent were identified through Fourier transform infrared spectrometry equipped with a diamond tipped ATR accessory (Shimadzu, Japan) at 4000 to $400 \mathrm{~cm}^{-1}$ wavelength. The spectra were arranged on transmittance axis before and after $\mathrm{Cr}$ adsorption onto the biosorbent. 
Zeta potential: The surface charge of water hyacinth biomass was determined by measuring zeta potential. About $0.5 \mathrm{mg}$ of biosorbent was mixed with $20 \mathrm{ml}$ of deionized water and the suspension was shaken at $180 \mathrm{rpm}$ for $2 \mathrm{hr}$ on a mechanical shaker. In order to shatter the particles into colloids, the suspension was left in sonic bath, and suspension was then filtered through Whatman no. 42 filter paper. Zeta potential was determined from the supernatant by zeta potential analyzer (Horiba Scientific)

Batch experiment: A set of preliminary experiments were conducted to determine the kinetic and equilibrium sorption behaviour of $\mathrm{Cr}(\mathrm{III})$ and $\mathrm{Cr}(\mathrm{VI})$. The trials were carried out at $25^{\circ} \mathrm{C}$ in $250 \mathrm{ml}$ conical flasks on a revolving shaker at $250 \mathrm{rpm}$. At the end of shaking period, the samples were centrifuged at $8000 \mathrm{rpm}$ for $10 \mathrm{~min}$ and filtered through Whatman no. 42 filter. The left over concentration of $\mathrm{Cr}$ ion was determined by Atomic Absorption Spectroscopy (Perkin Elmer 400).

Point of zero charge of biosorbent: Solid addition method was used to determine the point of zero charge $\left(\mathrm{pH}_{\mathrm{pzc}}\right)$ (Oladoja and Aliu, 2009). $\mathrm{pH}_{\mathrm{PzC}}$ was calculated by plotting the differences in $\mathrm{pH}$ value $\left(\Delta \mathrm{pH}=\mathrm{pH}_{\text {initial- }} \mathrm{pH}_{\text {final }}\right)$ against $\mathrm{pH}_{\text {initial }}$ and the point of intersection gave $\mathrm{pH}_{\mathrm{PzC}}$.

Effect of $\mathrm{pH}$ on biosorption: A set of preliminary experiments were conducted with 4 replicates. The concentration of $\mathrm{Cr}$ ion taken was $200 \mathrm{mg} \mathrm{l}^{-1}$ and the $\mathrm{pH}$ was adjusted from 1 to 9 using 1.0 N NaOH or $1.0 \mathrm{~N} \mathrm{HCl}$. The $\mathrm{pH}$ was measured using $\mathrm{pH}$ meter.

Kinetic study: The chromium adsorption rate and its mechanisms were elucidated through kinetic studies. To analyse the adsorption kinetics of $\mathrm{Cr}(\mathrm{III})$ and $\mathrm{Cr}(\mathrm{VI})$, the elovich, intra particle diffusion, pseudo first order and pseudo second order models were applied. In $250 \mathrm{ml}$ conical flask, $2 \%$ water hyacinth biomass was added in $200 \mathrm{mg} \mathrm{l}^{-1}$ of $\mathrm{Cr}(\mathrm{III})$ and $\mathrm{Cr}(\mathrm{VI})$ solutions with the pH adjusted to 5 and 2, respectively with $1.0 \mathrm{~N} \mathrm{NaOH}$ or $1.0 \mathrm{~N} \mathrm{HCl}$. The suspension was maintained in a revolving shaker at $250 \mathrm{rpm}$ for 6 to $48 \mathrm{hr}$ at $25^{\circ} \mathrm{C}$. The suspension was centrifuged, filtered and measured as described above. From deducting the remaining quantity from initial concentration, the quantity adsorbed was calculated. The adsorption kinetics was analyzed for $\mathrm{Cr}(\mathrm{III}, \mathrm{VI})$, the pseudo first order, pseudo second order, elovich and intra particle diffusion models were applied as described by Lagergren (1898); Ho and McKay (1999).

Isotherm study: The symmetrical relationship between sorbate and sorbent were determined by using the solution concentrations from 100 to $2000 \mathrm{mg} \mathrm{l}^{-1}$ through $100 \mathrm{mg} \mathrm{l}^{-1}$ interval with $\mathrm{pH} 2$ and 5 for $\mathrm{Cr}(\mathrm{VI})$ and $\mathrm{Cr}(\mathrm{III})$, respectively. Then the mixture of $100 \mathrm{ml}$ of each solution and $2.0 \mathrm{~g}$ of adsorbent were agitated on a rotating shaker at $250 \mathrm{rpm}$ and $25^{\circ} \mathrm{C}$ for $24 \mathrm{hr}$. The data obtained were fitted to Langmuir, Freundlich and Temkin isotherms as defined by Langmuir (1918), Dada et al. (2012) and Tempkin and Pyzhev (1940), respectively.

\section{Results and Discussion}

The morphology of adsorbent was analysed with Scanning Electron Microscope before and after the adsorption of $\mathrm{Cr}$ ions at $7.00 \mathrm{kV}$ equipped with back scattered electron detector. Fig.1 (a, e) shows the scanning electron micrograph of biomass with clear striated and nebulous structure which transformed to an aggregated structure after the adsorption of $\mathrm{Cr}$ (III) and $\mathrm{Cr}(\mathrm{VI})$ ions. This difference in surface structure of $\mathrm{Cr}$ (III) and $\mathrm{Cr}(\mathrm{VI})$ loaded adsorbent could be due to the deposition of chromium ions on the surface of the adsorbent (Balarak et al., 2014; Premalatha et al., 2019). EDAX spectra were recorded to assess the elemental composition of adsorbent before and after $\mathrm{Cr}$ adsorption. After $\mathrm{Cr}(\mathrm{III})$ and $\mathrm{Cr}(\mathrm{VI})$ adsorption, the composition of Ca reduced from $2.19 \%$ to 0.96 and $1.99 \%$, respectively. Similarly, the composition of $\mathrm{Mg}, \mathrm{Cl}, \mathrm{K}$ decreased after $\mathrm{Cr}$ (III and $\mathrm{VI}$ ) adsorption. Especially in consideration with $\mathrm{Na}$, initially it was found to be $0.49 \%$ which decreased to $0 \%$ after $\mathrm{Cr}$ (III) adsorption. Chromium peaks were found only after subjection to $\mathrm{Cr}$ (III and $\mathrm{VI}$ ) loading. The peaks of $\mathrm{Ca}, \mathrm{O}, \mathrm{C}$ indicated the existence of functional groups like $-\mathrm{OH}$ and $-\mathrm{COOH}$ in the adsorbent (Jain et al., 2013). The EDAX spectra of biomass before $\mathrm{Cr}$ adsorption showed no prominent peaks of chromium whereas spectra after $\mathrm{Cr}(\mathrm{III})$ and $\mathrm{Cr}$ $(\mathrm{VI})$ adsorption produced prominent $\mathrm{Cr}$ peaks with the reduction in Ca peaks (Das and Guha, 2007). Similar reducing trend in composition of $\mathrm{Mg}$, $\mathrm{Na}$, Kand Cl was also observed.

The FTIR peaks of powdered biomass at 3332.39, $2919.70,2291.02,2111.67$ and $1615.09 \mathrm{~cm}^{-1}$ showed the presence of $-\mathrm{OH}, \mathrm{C}-\mathrm{H}, \mathrm{N}-\mathrm{H}, \mathrm{C} \equiv \mathrm{C}$ and $\mathrm{C}=\mathrm{O}$ groups, respectively. The peak at $3332.39 \mathrm{~cm}^{-1}$ was shifted to 3284.18 and $3282.25 \mathrm{~cm}^{-1}$ after the sorption of $\mathrm{Cr}(\mathrm{III})$ and $\mathrm{Cr}(\mathrm{VI})$, respectively, onto the biomass. Similar shift in the peaks corresponding to $\mathrm{C} \equiv \mathrm{C}$ group was also recorded. Especially, the peaks at 2291.02 and $2111.67 \mathrm{~cm}^{-1}$ observed in unloaded biomass disappeared in $\mathrm{Cr}$ (VI) loaded biomass but peaks at $2919.70 \mathrm{~cm}^{-1}$ remained unchanged after $\mathrm{Cr}$ (III) and $\mathrm{Cr}(\mathrm{VI})$ adsorption which confirmed that $\mathrm{C}-\mathrm{H}$ groups were not involved in adsorption. This chemical shift and disappearance of peaks corresponding to groups confirmed their contribution towards adsorption.

FTIR results of water hyacinth biomass in advance and after $\mathrm{Cr}$ (III and $\mathrm{VI}$ ) adsorption are shown in Fig. 2. The FTIR spectra before $\mathrm{Cr}$ adsorption (Fig. 2a) showed intense peaks at $2700-3500 \mathrm{~cm}^{-1}$ which represent -OH group stretching and $-\mathrm{NH}$ bonds (Jain et al., 2014) indicating the existence of amine and hydroxyl groups with the broad peak at $3332.39 \mathrm{~cm}^{-1}$. A strong spectral peak at $1024.98 \mathrm{~cm}^{-1}$ showed $\mathrm{C}-\mathrm{O}$ bonds stretching. The FTIR spectra of $\mathrm{Cr}$ (III) loaded biosorbent (Fig. 2b) had broad peaks at $3284.18 \mathrm{~cm}^{-1}$ and $1019.19 \mathrm{~cm}^{-1}$ showing the presence of hydroxyl, amine and $\mathrm{C}-\mathrm{O}$ bonds stretching. Fig. $2 \mathrm{c}$ represents the water hyacinth biomass after $\mathrm{Cr}(\mathrm{VI})$ adsorption, in which broad peak at $3321.78 \mathrm{~cm}^{-1}$ was due to $-\mathrm{OH}$ and $\mathrm{N}-\mathrm{H}$ groups. The strong peak at $1581.34 \mathrm{~cm}^{-1}$ has been attributed to $\mathrm{NH}_{3}$ group antisymmetric deformation, and peak at $1024.02 \mathrm{~cm}^{-1}$ was due to 
(a)

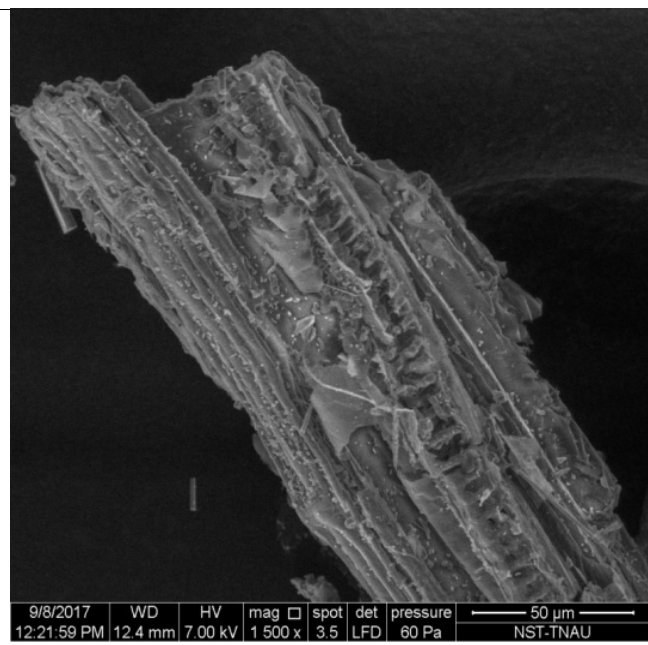

(c)

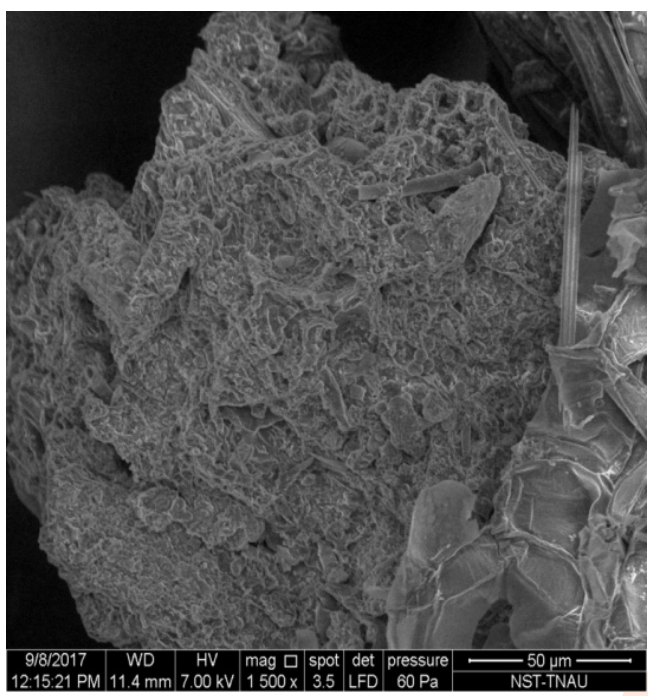

(e)

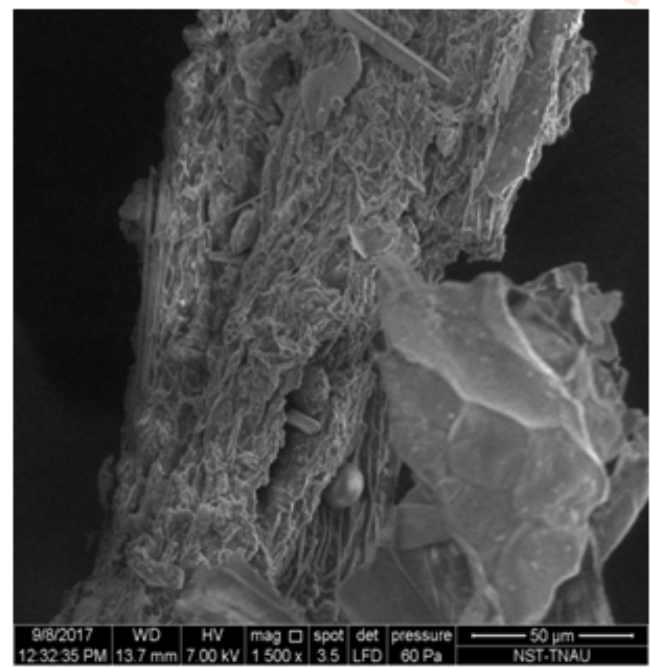

(b) c:ledax32lgenesislgenspc.spc 18-Sep-2017 15:25:16 10

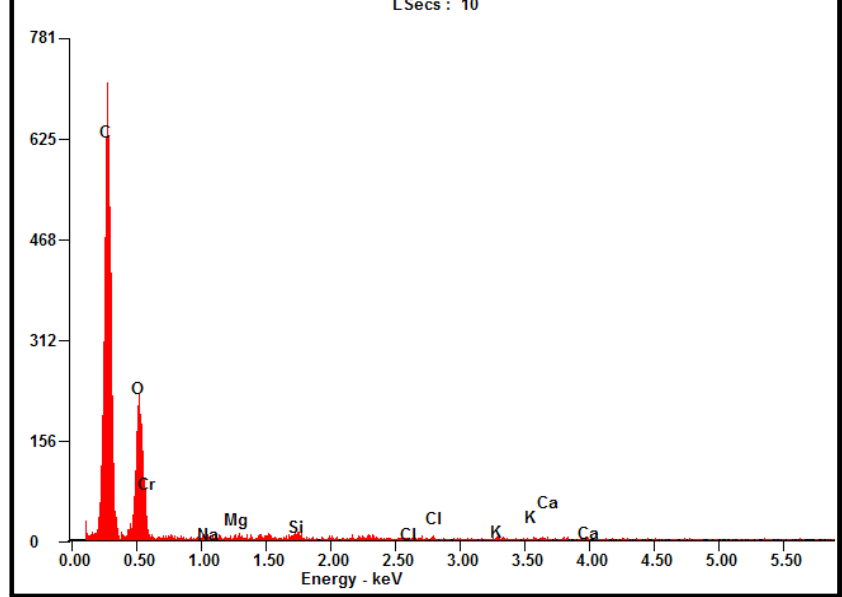

(d) c:ledax32lgenesislgenspc.spc 18-Sep-2017 15:34:05 : 10

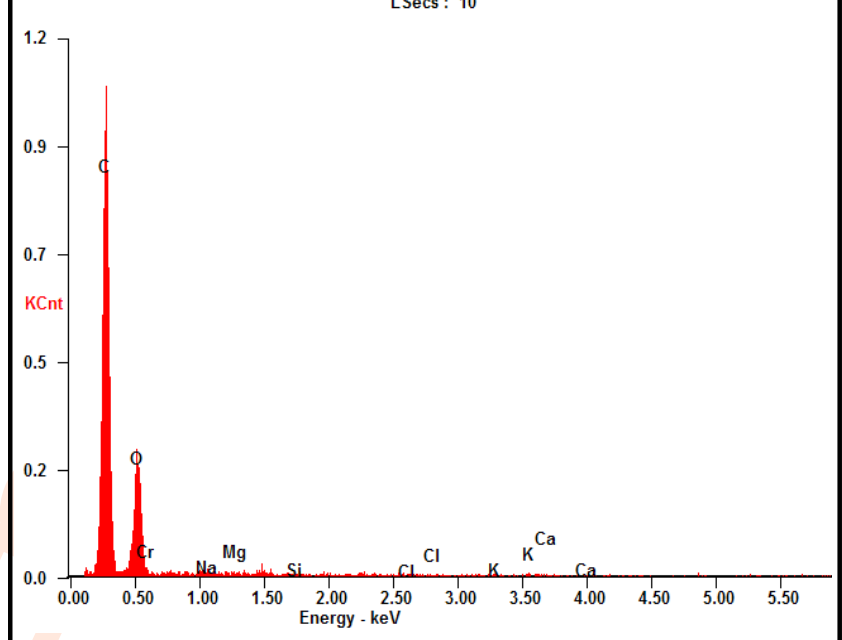

(f) c:ledax32lgenesislgenspc.spc 18-Sep-2017 15:29:35 LSecs : 10

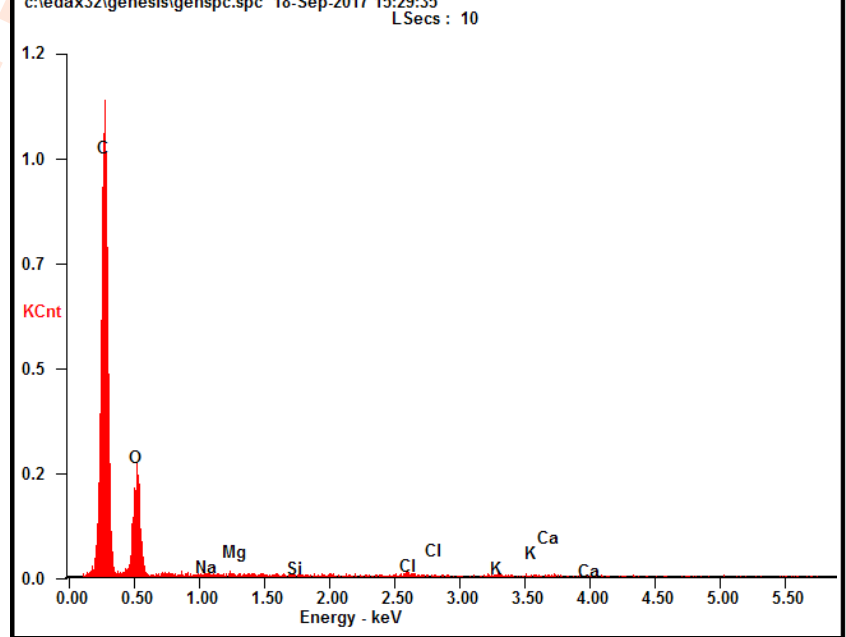

Fig. 1: (a) Scanning electron micrographs of water hyacinth biomass; (b) EDX of water hyacinth biomass; (c) Scanning electron micrographs of Cr (III) loaded biomass; (d) EDX of Cr (III) loaded biomass; (e) Scanning electron micrographs of Cr (VI) loaded biomass; (d) EDX of Cr (VI) loaded biomass. 

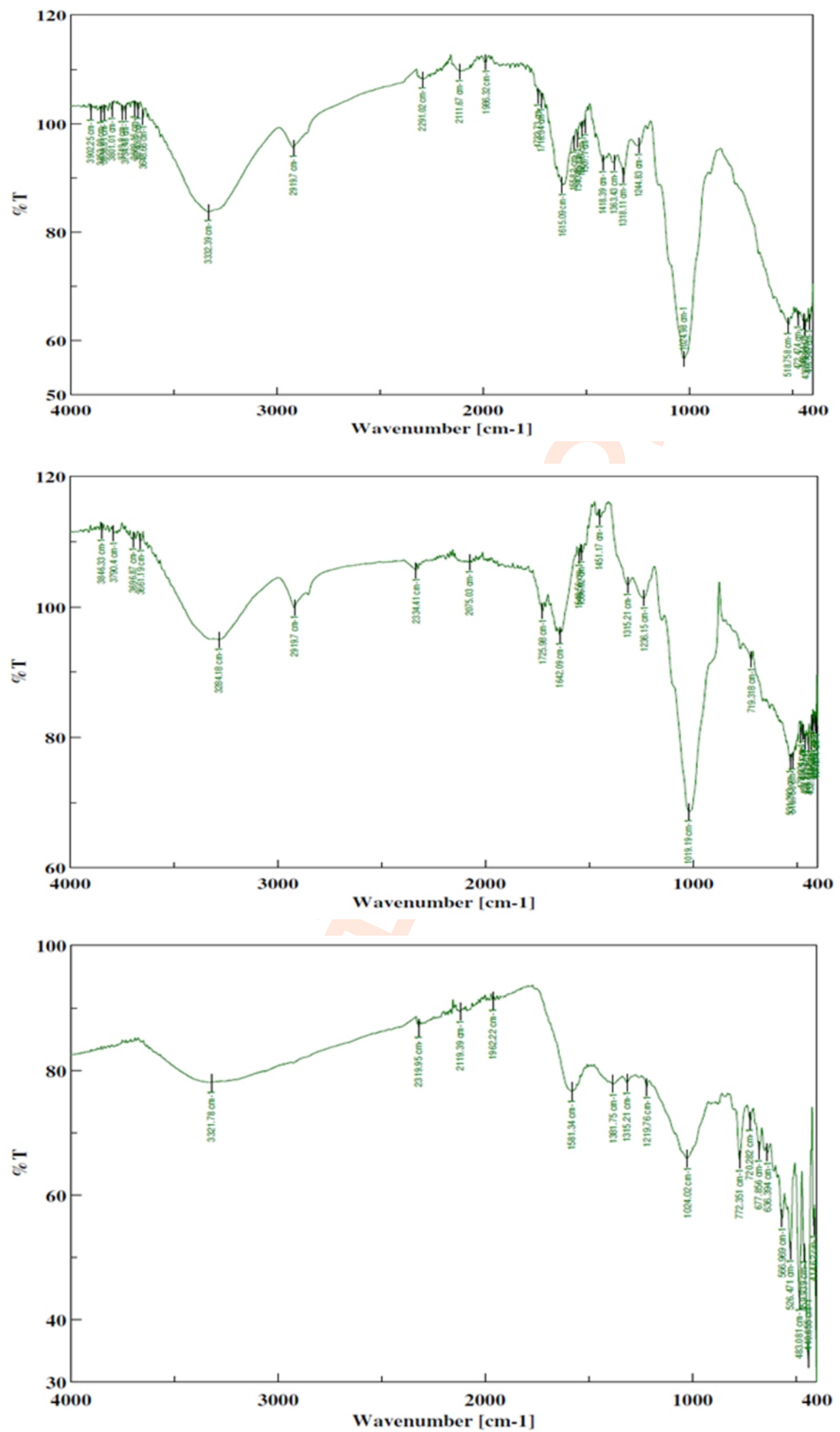

Fig. 2: FTIR spectra of water hyacinth biomass: (a) before Cradsorption; (b) after $\mathrm{Cr}$ (III) adsorption and (c) after $\mathrm{Cr}$ (VI) adsorption. 


\section{Zeta Potential Distribution}

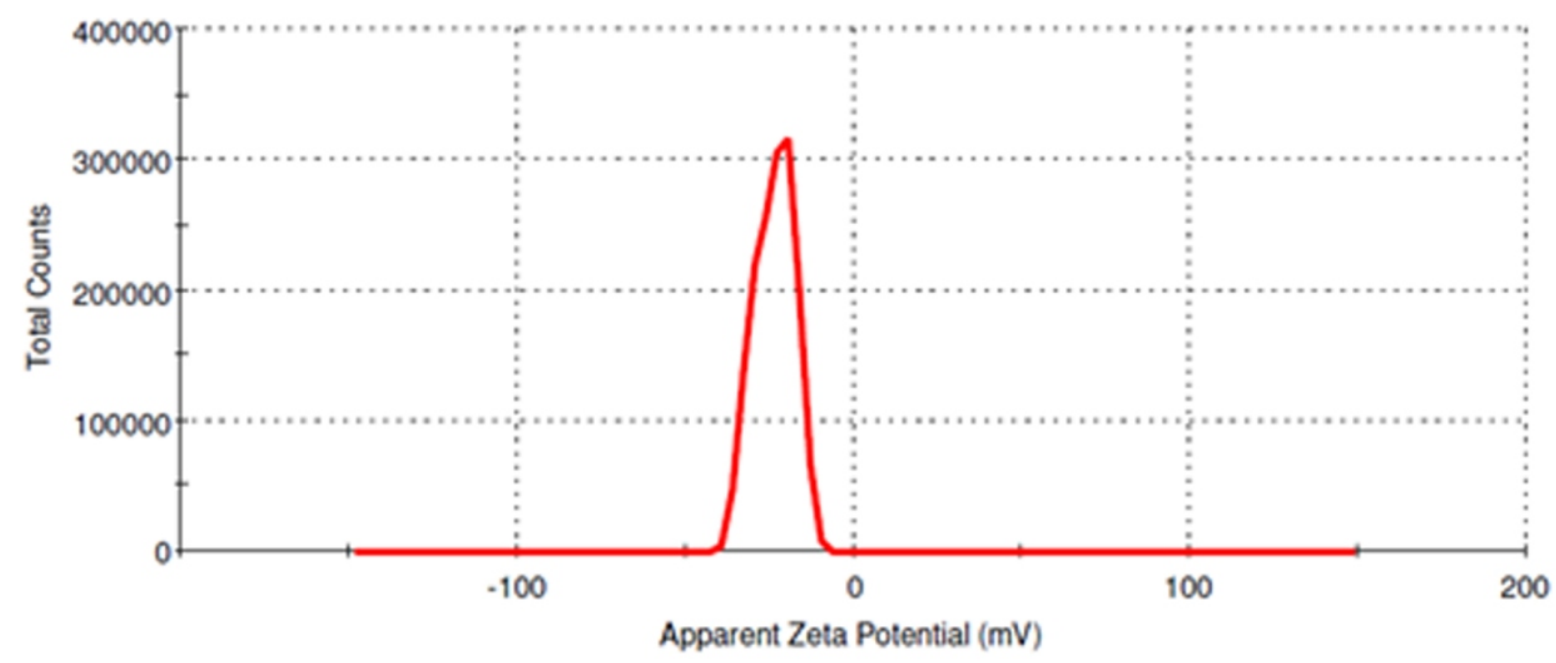

Record 4: UT 1

Fig. 3: Zeta potential distribution of water hyacinth biomass.

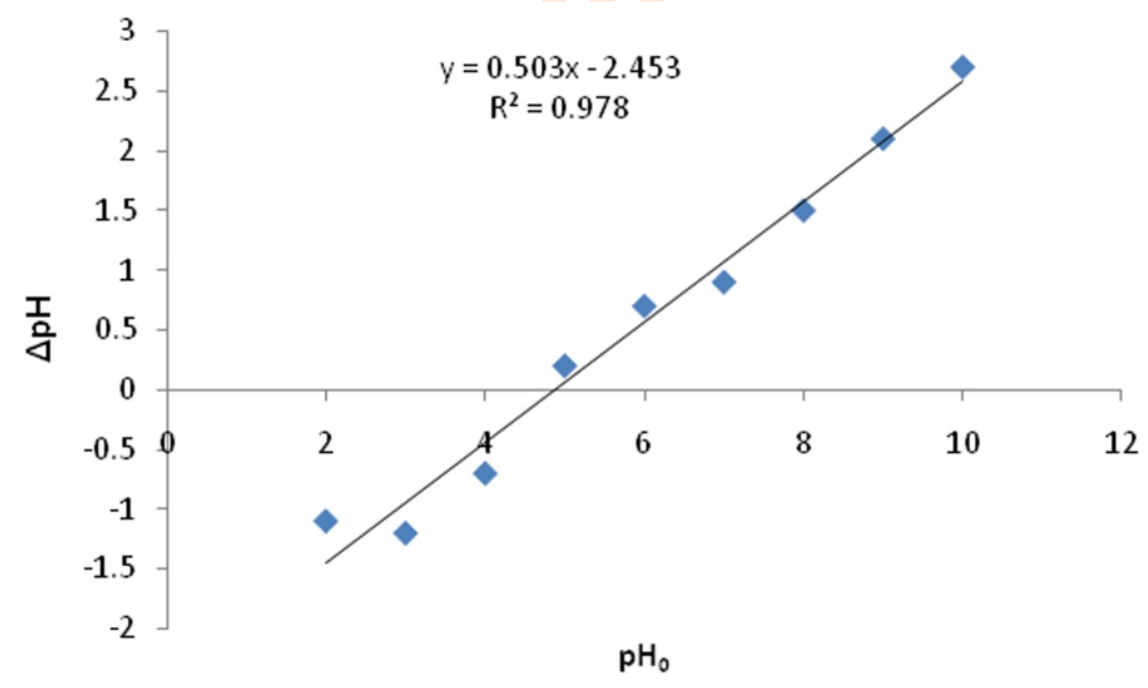

Fig. 4: Point of zero charge of water hyacinth biomass.

C-O functional groups. The distinct changes were recorded in spectra of biomass after $\mathrm{Cr}(\mathrm{III}$ and $\mathrm{VI})$ adsorption compared to spectra before $\mathrm{Cr}$ adsorption. The chemical shift in the positions of $-\mathrm{OH}, \mathrm{N}-\mathrm{H}$ and $\mathrm{C}-\mathrm{O}$ group peaks indicate their involvement in the biosorption of $\mathrm{Cr}(\mathrm{III})$ and $\mathrm{Cr}(\mathrm{VI})$. Biosorption process occurs due to smaller shift in the series of peak indicating the involvement of $\mathrm{NH}, \mathrm{OH}, \mathrm{C}=\mathrm{O}$ groups for binding the metal ions (Madhusudhanan et al., 2019). Zeta potential of water hyacinth biomass had negative surface charge of (-) $23.5 \mathrm{mV}$ (Fig.3.). The adsorbent recorded a negative zeta potential which indicated predominance of negative charges on the adsorbent surface, so cation like $\mathrm{Cr}$ (III) can be adsorbed more favourably compared to 

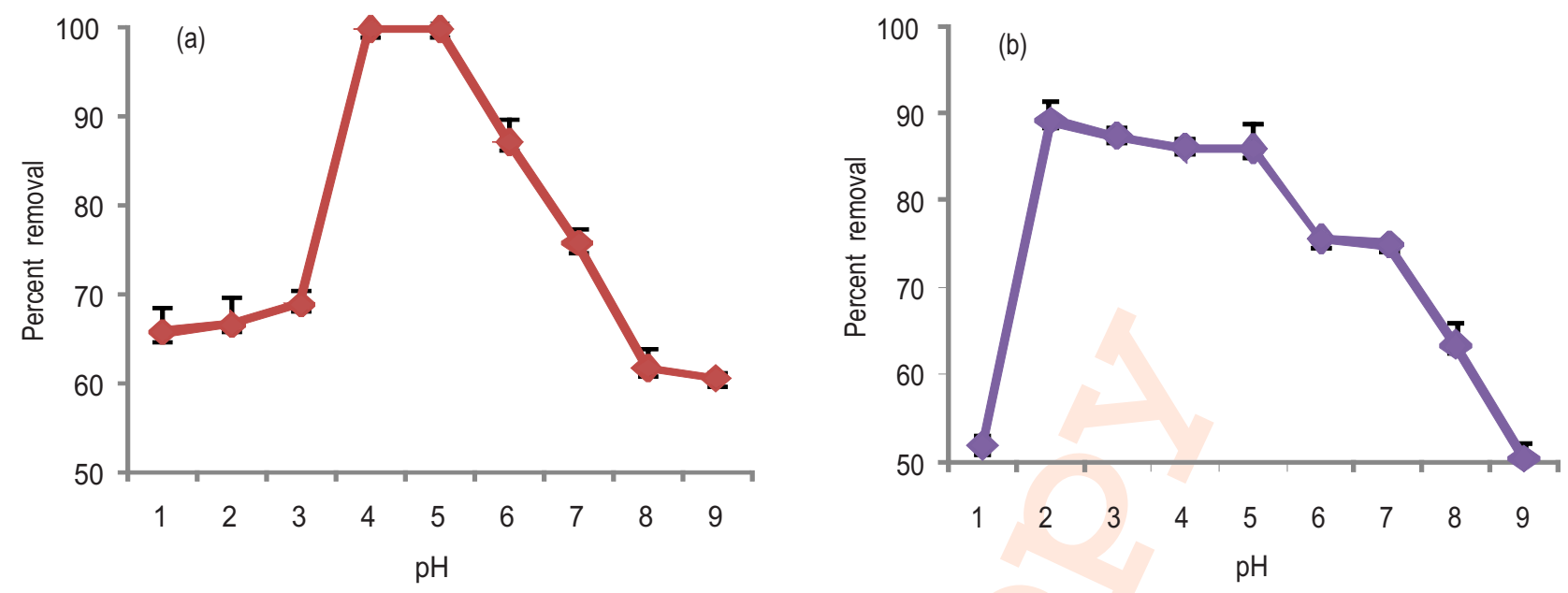

Fig. 5A: Effect of solution pH on: (a) $\mathrm{Cr}$ (III) and (b) $\mathrm{Cr}(\mathrm{VI})$ adsorption.
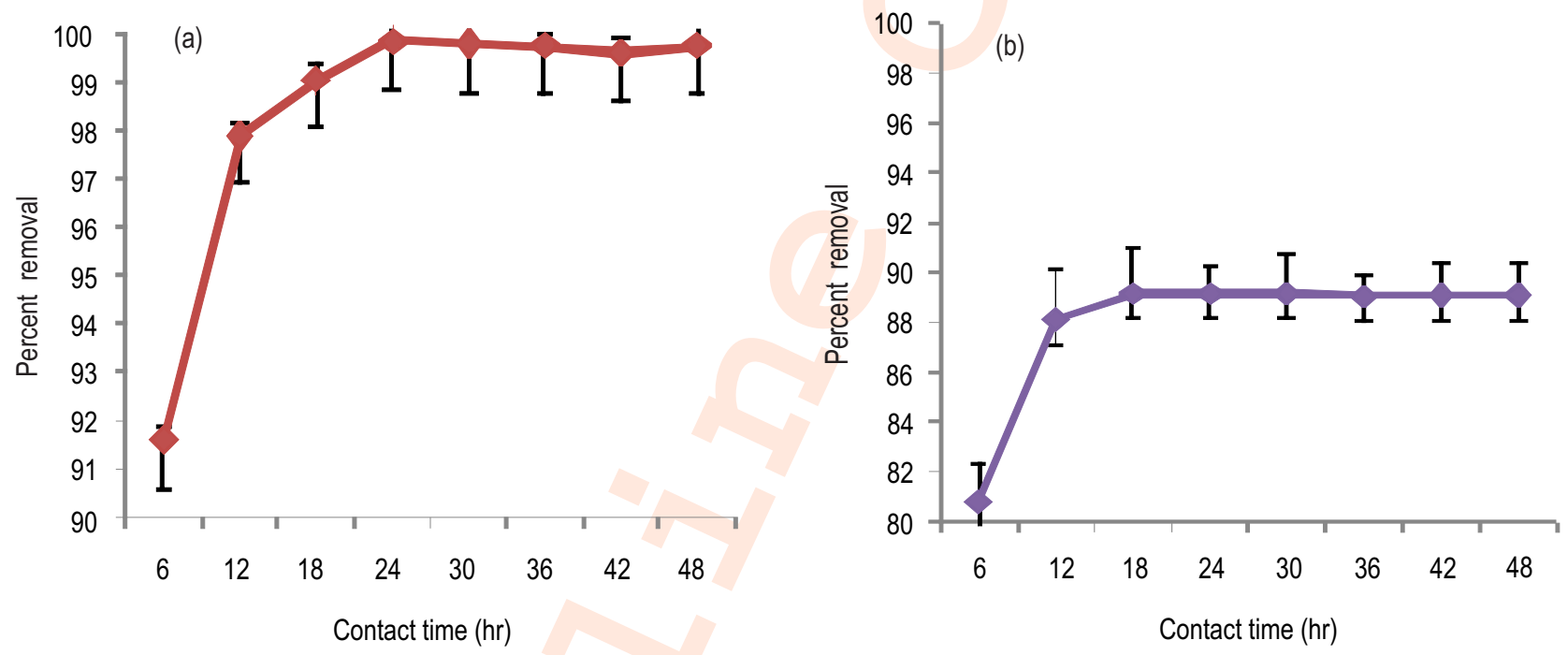

Fig. 5B: Effect of equilibrium period (hours) on: (a) $\mathrm{Cr}$ (III) and (b) $\mathrm{Cr}$ (VI) adsorption.

$\mathrm{Cr}(\mathrm{VI})$, which exists as anion. Based on the zeta potential measurements it seems that the adsorption process also includes the complexation reaction (Ghanbariana et al., 2018). The point of zero charge (PZC) means the $\mathrm{pH}$ where the net charge on surface of the bioadsorbent is zero, having higher positive charge functions as that of negative charge functions on the surface. Point of zero charge of an adsorbent is a useful parameter for determining the sorption of metal ions.

The plot between $\Delta \mathrm{pH}$ and $\mathrm{pHO}$ (Fig.4) shows that the point of zero charge of water hyacinth biomass was 4.8 . The sorption of metal ions depends on the surface chemistry of the adsorbents (He and Tebo, 1998). The adsorbent surface modifies its polarization according to the $\mathrm{pH}$ of the solution (Do Nascimento et al., 2013). At $\mathrm{pH}>\mathrm{pH}_{\mathrm{pzc}}$, the surface of the adsorbent become negatively charged due to the sorption of $\mathrm{OH}^{-}$ ions by electrostatic attractive force, favouring the adsorption of cations whereas when $\mathrm{pH}<\mathrm{pH}_{\mathrm{pzc}}$, adsorbent surface attains positive charge due to the adsorption of $\mathrm{H}^{+}$ions (Uddin et al., 2014). Hence, the adsorption of anionic metals $(\mathrm{Cr}(\mathrm{VI}))$ favors $\mathrm{pH}$ $<\mathrm{pH}_{\mathrm{pzc}}$ (Ebrahimian et al., 2014). The adsorbent characteristics and level of ionization of metal ions in aqueous solution depends on the pH of the solution (Xu et al., 2008; Puentes-Cárdenas et al., 2012). As the $\mathrm{pH}$ of the aqueous solution is a prime variable pertaining to the metals adsorption on the adsorbent, the effect of $\mathrm{pH}$ on removal of chromium by adsorbents was studied with $\mathrm{pH}$ 


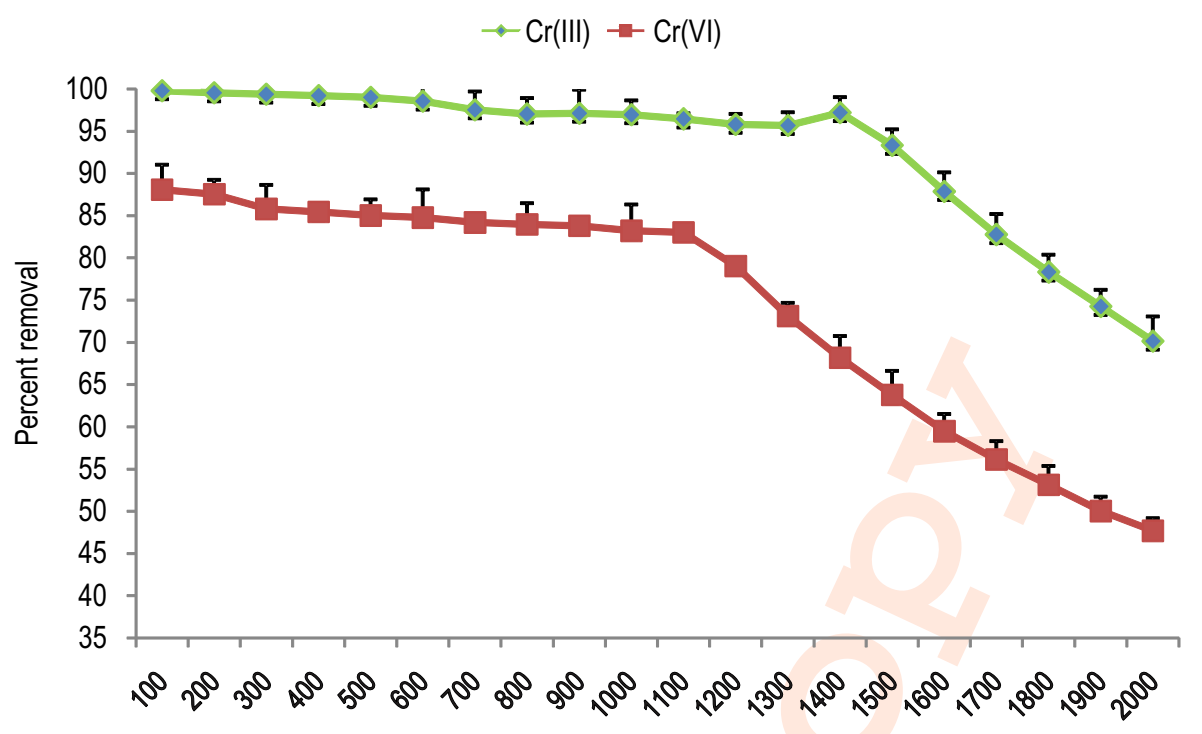

Solute concentration $\left(\mathrm{mgl}^{-1}\right)$

Fig. 5C: Effect of solute concentration on removal of $\mathrm{Cr}(\mathrm{III}, \mathrm{VI})$.

range of 1 to 9 (Fig. 5A). The results showed that the maximum removal of $\mathrm{Cr}(\mathrm{VI})(89.2 \%)$ was achieved at $\mathrm{pH}$ 2.0. Similarly, $\mathrm{Cr}$ (III) removal by the biomass $(99.8 \%)$ was maximum at $\mathrm{pH} 5.0$. Variation in the removal of $\mathrm{Cr}(\mathrm{III})$ and $\mathrm{Cr}(\mathrm{VI})$ at different $\mathrm{pH}$ may be attributed to the factors like charge of metal ions in aqueous solution and charge on the adsorbent surface at particular $\mathrm{pH}$. In aqueous solution, trivalent $\mathrm{Cr}$ is present as a cation whereas hexavalent $\mathrm{Cr}$ is present as anion (Bedemo et al., 2016). It has been inferred that, at lower $\mathrm{pH}$ the surface of the adsorbent acquires a positive charge which can easily bind negatively charged $\mathrm{Cr}(\mathrm{VI})$ through electrostatic force of attraction (Tarley and Arruda, 2004; Mohanty et al., 2006). In addition, lower adsorption of cations ( $\mathrm{Cr}$ (III) at low $\mathrm{pH}$ may be due to the competition of $\mathrm{H}^{+}$and metal ions (Banat et al., 2007) and electrostatic repulsion (Jeon and Höll, 2003).

At moderate $\mathrm{pH}$ ( 3 to 6 ), the $\mathrm{H}^{+}$ions linked with active sites of adsorbent are released favouring the adsorption of metal cations but at higher $\mathrm{pH}(>6.0)$, the precipitation of metals and hydroxide formation dominates restricting the metal sorption (Salehzadeh, 2013). At higher $\mathrm{pH}$, the surface charge of the adsorbent becomes negative and increases the percent removal of $\mathrm{Cr}$ (III) (Chathuranga et al., 2013). The solute concentration and contact time has profound influence on the adsorption phenomenon which is depicted in Fig. 5. $(B, C)$. The major adsorption of $\mathrm{Cr}(\mathrm{III})(91.60 \%)$ and $\mathrm{Cr}(\mathrm{VI})(80.80 \%)$ occurred at 6 $\mathrm{hr}$ and at equilibrium 99.85 and $89.14 \%$ of $\mathrm{Cr}(\mathrm{III})$ and $\mathrm{Cr}(\mathrm{VI})$, respectively were adsorbed. The initial rapid adsorption of cations could be due to large number of active sites available for adsorption and later the balance active sites were hard to be engaged due to repulsive action between solute molecules of both bulk and solid phases (Alslaibi et al., 2014). The unit $\mathrm{Cr}$ adsorption increased markedly with increase in solute concentration, the percent removal was found to decrease with higher adsorbate concentration. The results showed that the maximum removal of $\mathrm{Cr}(\mathrm{III})(99.8 \%)$ and $\mathrm{Cr}(\mathrm{VI})(88.1 \%)$ by the biomass was recorded with $100 \mathrm{mg} \mathrm{l}^{-1}$ solute concentration, beyond which the metal removal decreased. On increasing the solute concentration, the sorption capacity increased but decreased the removal percent, which might be due to lack of active binding sites required at higher solute concentration of aqueous solution (Martinez et al., 2006; Freitas et al., 2008).

The kinetics involved in the $\mathrm{Cr}(\mathrm{III})$ and $\mathrm{Cr}(\mathrm{VI})$ adsorption onto the biomass was tested with kinetic models namely pseudo first order, pseudo second order, elovich and intra particle diffusion model (Fig. 6A,B). The high $\mathrm{R}^{2}$ value of 0.999 each for $\mathrm{Cr}$ (III) and $\mathrm{Cr}(\mathrm{VI})$ was obtained from pseudo second order kinetic model. Also, the calculated value of $\mathrm{q}_{\mathrm{e}}$ was closer to the experimental $q_{e} v a l u e$ in pseudo second order model. For instance, the qualue calculated for $\mathrm{Cr}$ (III) and $\mathrm{Cr}(\mathrm{VI})$ adsorption onto biomass was 10.1 and $9.01 \mathrm{mg} \mathrm{g}^{-1}$, were in close agreement with experimental qualue of 9.99 and $8.91 \mathrm{mg} \mathrm{g}^{-1}$ for $\mathrm{Cr}$ (III) and $\mathrm{Cr}$ (VI), respectively, but for pseudo first order model. The calculated

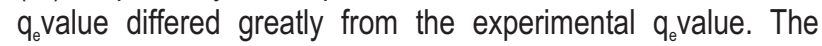
elovich equation was also employed to study the adsorption phenomena, but low $\mathrm{R}^{2}$ was recorded. From elovich kinetics, $\mathrm{a}$ which denotes the initial adsorption rate was found maximum for adsorption of $\mathrm{Cr}$ (III) onto biomass $\left(2.926 \times 10^{10} \mathrm{mg} \mathrm{g}^{-1} \mathrm{~min}^{-1}\right)$. In addition, the number of binding sites accessible for $\mathrm{Cr}$ adsorption related to the parameter $1 / \beta$ showed higher values of 0.35 and 


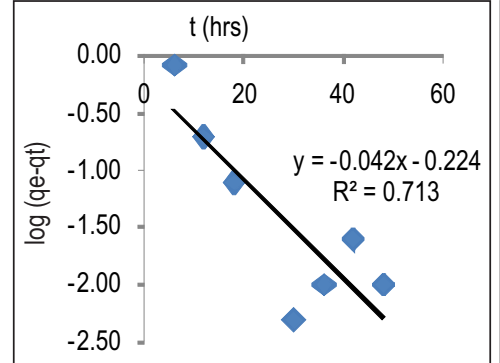

(a) Pseudo first order kinetic model

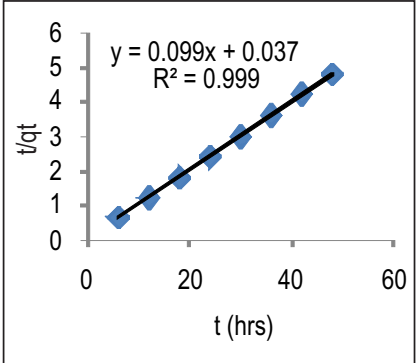

(b) Pseudo second order kinetic model

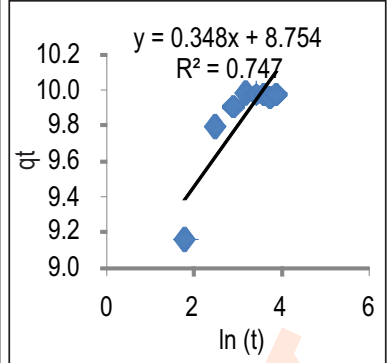

(c) Elovich model

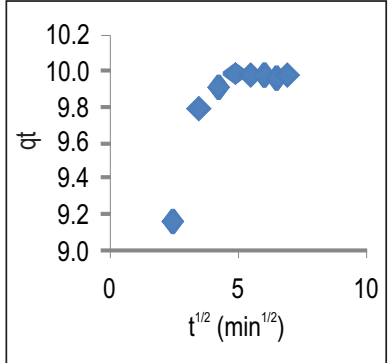

(d) Intraparticle diffusion model

Fig. 6A: Adsorption kinetics for $\mathrm{Cr}($ (III) adsorption by water hyacinth biomass.

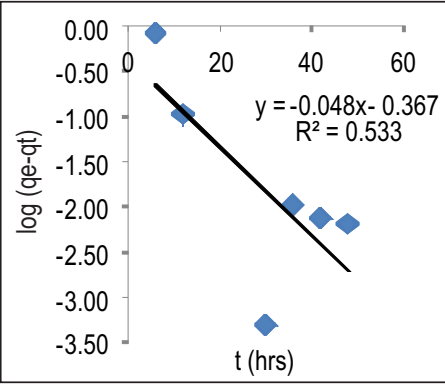

(a) Pseudo first order kinetic model

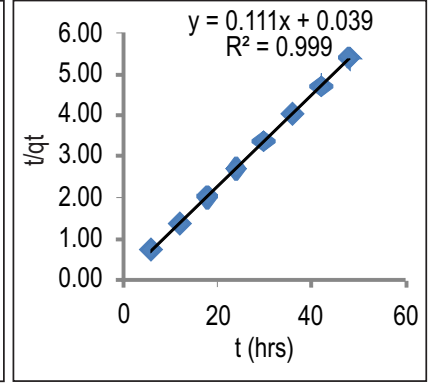

(b) Pseudo second order kinetic model

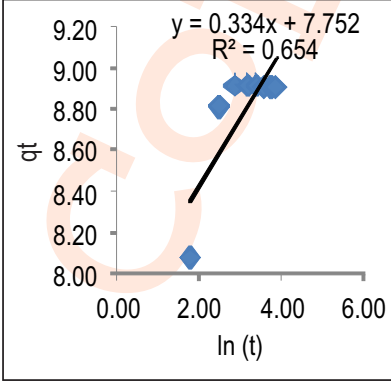

(c) Elovich model

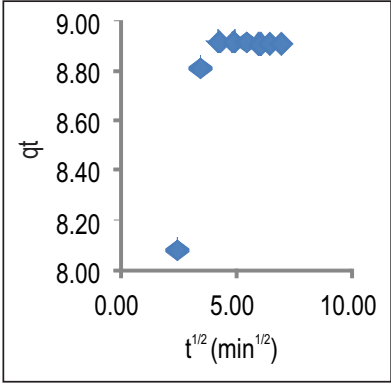

(d) Intraparticle diffusion model

Fig. 6B: Adsorption kinetics for $\mathrm{Cr}(\mathrm{VI})$ adsorption by water hyacinth biomass.

$0.81 \mathrm{mg} \mathrm{g}^{-1}$ for $\mathrm{Cr}(\mathrm{III})$ and $\mathrm{Cr}(\mathrm{VI})$, respectively. The $\mathrm{R}^{2}$ and $\mathrm{q}_{\mathrm{e}}$ value of pseudo second order model suggests that $\mathrm{Cr}$ (III) and $\mathrm{Cr}(\mathrm{VI})$ adsorption could be better described by chemisorption (Bernard and Jimoh, 2013; Chakraborty et al., 2020) which involves sharing of electrons between adsorbents and adsorbate (Deng et al., 2009). To obtain valid information pertaining to process involved in the adsorption mechanism, the data were further examined by intra particle diffusion model.

The multi linear plots were obtained from diffusion model which revealed that two or many steps were associated with the sorption of Cr onto the adsorbent (El-Said, 2010). From the plots of intra particle diffusion model, twin linearity was observed which confirmed that adsorption process involved two steps. The first linear portion represents the boundary layer diffusion of metal ions to the exterior surface of the adsorbent, while the next linear portion represents the intra particle diffusion (Abdel-Ghani et al., 2015). To understand the adsorption mechanism at solid/liquid interface, Langmuir, Freundlich and Temkin isotherm models were studied. The isotherm plots for $\mathrm{Cr}(\mathrm{III})$ and $\mathrm{Cr}(\mathrm{VI})$ adsorption are shown in Fig. 7 A,B. For adsorbent and $\mathrm{Cr}$ species, the maximum $R^{2}$ value was obtained in Langmuir isotherm which confirmed that adsorption of $\mathrm{Cr}$ (III, $\mathrm{VI}$ ) onto adsorbents occurred onto the active sites as monolayer (Abdel-Aty et al., 2013). The Langmuir dimensionless constant $\left(K_{R}\right)$ for each of the solute concentration was found between 0 and 1 , indicating favourable adsorption of $\mathrm{Cr}(\mathrm{III} \& \mathrm{VI})$ onto the adsorbents (Kadirvelu et al., 2001). For $\mathrm{Cr}$ (III), the maximum monolayer adsorption capacity $\left(\mathrm{q}_{\mathrm{m}}\right)$ of 76.9 and $41.7 \mathrm{mg} \mathrm{g}^{-1}$ was reported. Similarly, the $\mathrm{q}_{\mathrm{m}}$ for $\mathrm{Cr}(\mathrm{VI})$ was 53.2. For $\mathrm{Cr}$ (III) adsorption, $\mathrm{KL}$ values of 0.084 whereas opposite trend was noticed for $\mathrm{Cr}(\mathrm{VI})$ adsorption. From the constants $\left(\mathrm{q}_{\mathrm{m}}\right.$ and $\mathrm{KL}$ ), it was clear that biomass had higher sorption capacity of $\mathrm{Cr}$ (III) than $\mathrm{Cr}(\mathrm{VI})$. Freundlich isotherm model showed $\mathrm{R}^{2}$ value of 0.864 and 0.821 for $\mathrm{Cr}(\mathrm{III})$ and $\mathrm{Cr}(\mathrm{VI})$, respectively.

The calculated isotherm data revealed that adsorption intensity given by Freundlich coefficient $(1 / n)$ was $<1$, indicated positive adsorption of $\mathrm{Cr}(\mathrm{III})$ and $\mathrm{Cr}(\mathrm{VI})$ onto the water hyacinth biomass as biosorbent (Varank et al., 2012; Erhayem and Sohn, 2014). Adding this, the higher sorption capacity $\left(K_{F}\right)$ was achieved (12.02 $\left.\mathrm{mg} \mathrm{g}^{-1}\right)$ for $\mathrm{Cr}(\mathrm{III})$ than $\mathrm{Cr}(\mathrm{VI})\left(2.45 \mathrm{mg} \mathrm{g}^{-1}\right)$, which confirmed greater sorption of $\mathrm{Cr}$ (III) onto the biosorbent than $\mathrm{Cr}(\mathrm{VI})$ (Ismail et al., 2013). The outcome represents that the higher $R^{2}$ value of $0.999(\mathrm{Cr}(\mathrm{III}))$ and $0.989(\mathrm{Cr}(\mathrm{VI}))$ were obtained from Langmuir isotherm model, which confirmed that biosorption of $\mathrm{Cr}(\mathrm{III})$ and $\mathrm{Cr}(\mathrm{VI})$ onto biosorbent occurred onto the active sites as monolayer (Adbel- Aty et al., 2013). Adsorption of metal ions on biosorbent surface was found over unity (n values), indicating active adsorption (Singh et al., 2018). Considering Freundlich isotherm, the $R^{2}$ value was less compared to Langmuir and 


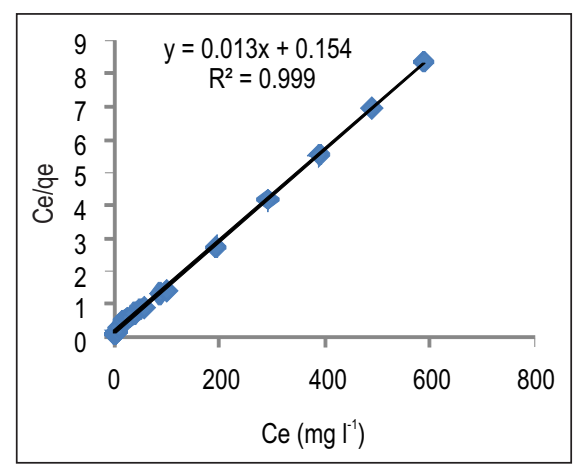

(a) Langmuir isotherm

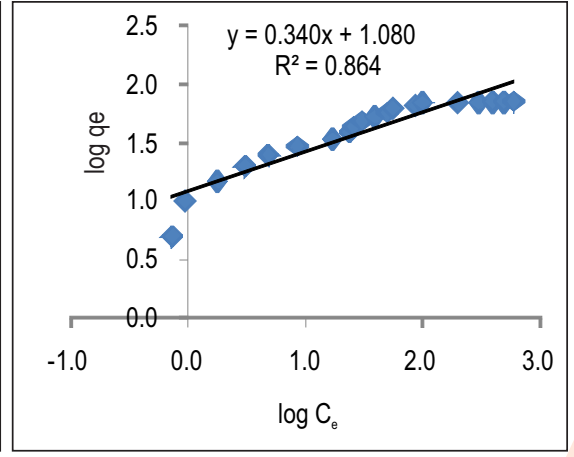

(b) Freundlich isotherm

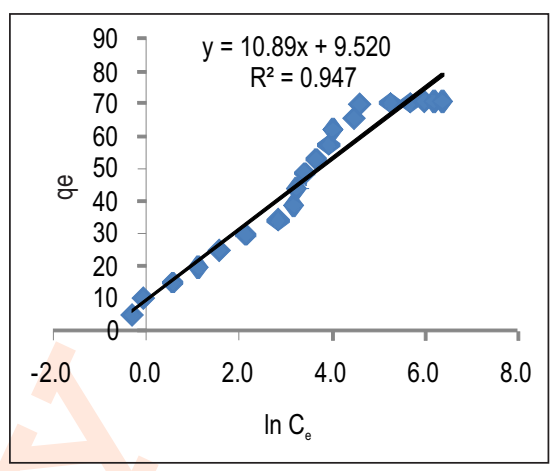

(c) Temkin isotherm

Fig. 7A: Adsorption isotherms for $\mathrm{Cr}(\mathrm{III})$ adsorption by water hyacinth biomass.

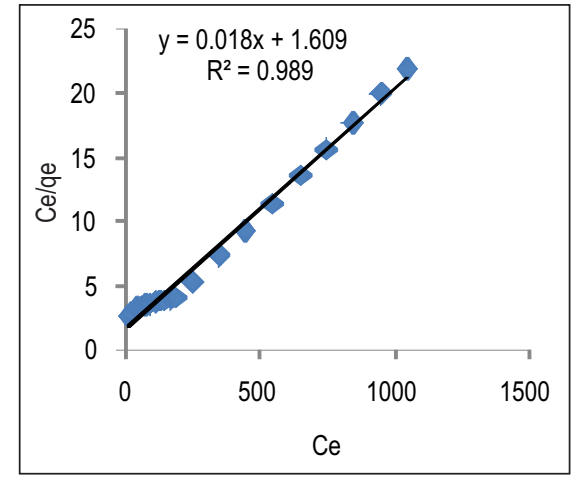

(a) Langmuir isotherm

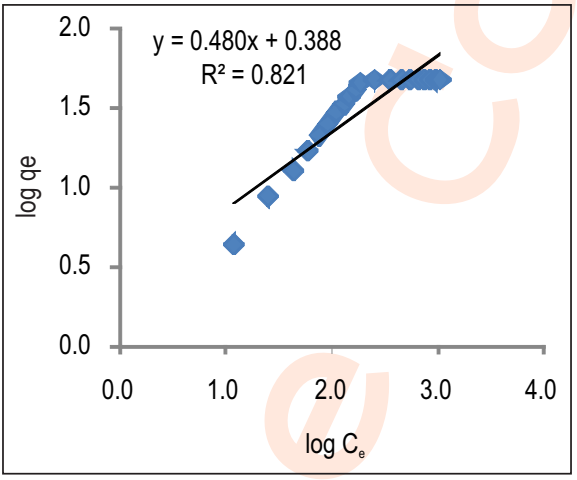

(b) Freundlich isotherm

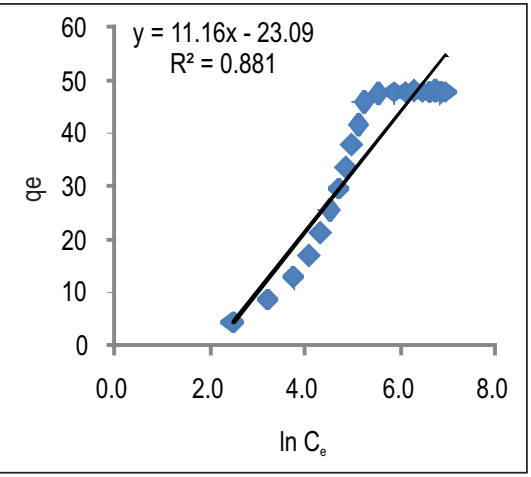

(C) Temkin isotherm

Fig. 7B: Adsorption isotherms for $\mathrm{Cr}(\mathrm{VI})$ adsorption by water hyacinth biomass.

Temkin isotherms and the ' $n$ ' value for both adsorbents and $\mathrm{Cr}$ species ranged between 2-3, indicated favourable adsorption (Mckay et al., 1980). Adding this, the Freundlich constant related to sorption capacity (KF) was found maximum $\left(12.0 \mathrm{mg} \mathrm{g}^{-1}\right)$ for $\mathrm{Cr}$ (III) than $\mathrm{Cr}(\mathrm{VI})\left(2.45 \mathrm{mg} \mathrm{g}^{-1}\right)$ for biomass. From this study it is concluded that water hyacinth biomass is a potential biosorbent with variable capacity to remove $\mathrm{Cr}$ (III) and $\mathrm{Cr}(\mathrm{VI})$. SEM with EDX and FTIR analysis confirmed the adsorption reaction on biosorbent surface. Hence, water hyacinth biomass is more efficient in $\mathrm{Cr}$ (III) adsorption than $\mathrm{Cr}(\mathrm{VI})$. From this study, it is evident that water hyacinth based biosorbent will act as an ecofriendly biosystem for the management of chromium contamination while considering the economic aspects of wastewater treatment. Hence, this technology may be upgraded to larger scale in the industries.

\section{Acknowledgment}

The authors deeply acknowledge the Science and Engineering Research Board (YSS/2015/001432), Department of Science and Technology, New Delhi for financial assistance.

\section{Add-on Information}

Authors' contribution: E. Parameswari: Designed \& Executed the study; R.P. Premalatha: Wrote the protocol \& conducted the experiment; V. Davamani: Wrote the first draft of the manuscript; P. Kalaiselvi: Statistical analysis \& draft editing; S. Paul Sebastian: Manage the analyses of the study; K. Suganya: Manage the literature search.

Research content: The research contents is original and has not been published elsewhere

\section{Ethical approval: NotApplicable}

Conflict of interest: The author declare that there is no conflict of interest.

\section{Data from other sources: NotApplicable}

Consent to publish: Author agree to publish the paper in Journal of Environmental Biology. 


\section{References}

Abdel-Aty, A., N.S. Ammar, H.H.A. Ghafar and R.K. Ali: Biosorption of cadmium and lead from aqueous solution by fresh water alga Anabaena sphaerica biomass. J. Adv. Res., 4, 367-374 (2013).

Abdel-Ghani, N.T., G.A.G Chaghaby and E.M. Zahran: Pentachloro. phenol (PCP) adsorption from aqueous solution by activated carbons prepared from cornwastes. Int. J. Environ. Sci. Tech.,12, 211-222 (2015).

Abechi, E.S., C.E. GimbaUzaire and J.A. Kagbu: Kinetics of adsorption of methylene blue onto activated carbon prepared from palm kernel shell. Arch. Appl. Sci. Res., 3,154-164 (2011).

Akpor, O.B., G.O. Ohiobor and T.D. Olaolu: Heavy metals pollutants in waste water effluents: Sources, effects and remediation. Adv. Biosci. Bio Eng., 2, 37-43 (2014).

Alslaibai, T.M., I. Abustan, M.A. Ahmad and A.A. Foul: Comparative studies on the olive stone activated carbon adsorption of $\mathrm{Zn}^{2+}, \mathrm{Ni}^{2+}$ and $\mathrm{Cd}^{2+}$ from synthetic waste water. Desalin. Water Treat., 54,166-177 (2014).

Avudainayagam, S., M. Megharaj, G. Owens, R.S. Kookana, D. Chittleborough and R. Naidu: Chemistry of chromium in soils with emphasis on tannery waste sites. Rev. Environ. Contam. Toxicol., 178, 53-91 (2003).

Balarak, D., Y. Mahdavi, F. Gharibi and S. Sadeghi: Removal of hexavalent chromium from aqueous solution using canola biomass: Isotherms and kinetics studies. J. Adv. Environ. HIth. Res., 2, 234-241 (2014).

Banat, F., S. Al-Asheh, R. Al-Ahmad and F. Bni-Khalid: Bench scale and packed bed sorption of methylene blue using treated olive pomace and charcoal. Bioresour. Technol., 98, 3017-3025 (2007).

Bedemo, A., B.S. Chandravanshi and F. Zewge: Removal of trivalent chromium from aqueous solution using aluminium oxide hydroxide. Springer Plus, 5, 1288 (2016).

Bernard, E. and A. Jimoh: Adsorption of $\mathrm{Pb}, \mathrm{Fe}, \mathrm{Cu}$ and $\mathrm{Zn}$ from industrial electroplating waste water by orange peel activated carbon. $\mathrm{J}$. Eng. Appl. Sci., 4, 95-103 (2013).

Chakraborty, R., A. Asthana, A.K. Singh, B. Jain and A.B.H. Susan: Adsorption of heavy metal ions by various low-cost adsorbents: $A$ review. Int. J. Environ. Anal. Chem., 1-37 (2020). 10.1080/ 03067319.2020 .1722811$.

Chathuranga, P.K.D., N. Priyantha, S.S. Iqbal and M.C.M. Iqbal: Biosorption of $\mathrm{Cr}(\mathrm{III})$ and $\mathrm{Cr}(\mathrm{VI})$ species from aqueous solution by Cabomba caroliniana: Kinetic and equilibrium study. Environ. Earth Sci., 70, 661-671 (2013).

Dada, A.O., A.P. Olalekan, A.M. Olatunya and O. Dada: Langmuir, Freundlich, Temkin and Dubinin- Radushkevich isotherms studies of equilibrium sorption of $\mathrm{Zn}^{2+}$ onto phosphoric acid modified rice husk. IOSR J. Appl. Chem., 3, 38-45 (2012).

Das, S.K. and A.K. Guha: Biosorption of chromium by Termitomyces clypeatus. Colloids Surf B: Biointerfaces, 60, 46-54 (2007).

Deng, S., R. Ma, Q. Yu, J. Huang and G. Yu: Enhanced removal of pentachlorophenol and 2,4 -D from aqueous solution by an aminated biosorbent. J. Hazard. Mater., 165, 408 - 414 (2009).

Do Nascimento, R.F., C.W.B. Bezerra, H.A.S. Silva, M.S. Schultz and S.A.A. Santana: Effect of $\mathrm{pH}$ and improvement in violet remazol dye removal from water by Eichhornia crassipes (water hyacinth). Cad. Perq. Sao Luis., 20, 73-80 (2013)

Dubey, A., A. Mishra and S. Singhal: Application of dried plant biomass as novel low-cost adsorbent for removal of cadmium from aqueous solution. Int. J. Environ. Sci. Technol., 11, 1043-1050 (2014).

Ebrahimian, A., E.Saberikhan, M.S. Emami and M. Sotudeh: Study of biosorption parameters: Isotherms, kinetics and thermodynamics of basic blue of biosorption onto foumanat tea waste. Cellul. Chem. Technol., 48, 735-743 (2014).

El-Said, A.G.: Biosorption of $\mathrm{Pb}$ (II) ions from aqueous solutions onto rice husk and its ash. J. Am. Sci., 6, 143-150 (2010).

Erhayem, M. and M. Sohn: Effect of humic acid source on humic acid adsorption onto titanium dioxide nanoparticles. Sci. Total Environ., 470, 92-98 (2014).

Fomina, M. and G.M. Gadd: Biosorption: Current perspectives on concept, definition and application. Biores. Technol., 160, 3-14 (2014).

Freitas, O.M.M., R.J.E. Martins, C.M. Deleure-Matos and R.A.R. Boanventura: Removal of $\mathrm{Cd}(\mathrm{II}), \mathrm{Zn}(\mathrm{II})$ and $\mathrm{Pb}$ (II) from aqueous solutions by brown marine macro algae: Kinetic modeling. $\mathrm{J}$. Hazar. Mater., 153, 493-501 (2008).

Ghanbariana, M., R. Nabizadeha, S. Nasseria, F. Shemiranib, A.H. Mahvia, M.H. Beykib and A. Mesdaghinia: Effect of bioflocculants on the coagulation activity of alum for removal of trihalomethane precursors from low turbid water. J. Env. Sci., 70, 1-10 (2018).

Ghosh, D.: Water hyacinth-Befriending the noxious weed. Sci. Rep., 47, 46-48 (2010)

$\mathrm{He}$, L.M. and B.M. Tebo: Surface charge properties of and $\mathrm{Cu}(\mathrm{II})$ adsorption by spores of the marine Bacillus sp. strain SG-1. Appl. Environ. Microbiol., 64, 1123-1129 (1998).

Ho, Y.S. and G. McKay: Pseudo-second order model for sorption processes. Proc. Biochem., 34, 451-465 (1999)

Ismail, M.G.B.H., C.N. Weng, H.A. Rahman and N.A.Z akaria: Freundlich isotherm equilibrium equations in determining effectiveness a low cost absorbent to heavy metal removal in waste water (leachate) at TelukKitang landfill, Pengkalan Chepa, Kelantan, Malaysia. J. Geogr. Earth. Sci., 1, 01-08 (2013).

Jain, M., V.K. Garg and K. Kadirvelu: Chromium removal from aqueous system and industrial waste water by agricultural wastes. Biorem. J., 17, 30-39 (2013).

Jain, M., V.K. Garg and K. Kadirvelu: Removal of Ni(II) from aqueous system by chemically modified sunflower biomass. Desalin. Water Treat., 52, 5681-5695 (2014)

Jeon, C. and H. Holl: Chemical modification of chitosan and equilibrium study for mercury ion removal. Water Res., 37, 4770-4780 (2003).

Kadirvelu, K., K. Thamaraiselvi and C. Namasivayam: Adsorption of nickel (II) from aqueous solution onto activated carbon prepared from coirpith. Sep. Purif. Technol., 24, 497-505 (2001).

Kamaludeen, S.P.B., K.R. Arunkumar, S. Avudainayagam and K. Ramasamy: Bioremediation of chromium contaminated environments. Indian J. Exp. Biol., 41, 972-985 (2003).

Khatoon, N., A.H. Khan, V. Pathak, N. Agnihotri and M Rehman: Removal of hexavalent chromium from synthetic waste water using synthetic nano zero valent iron (NZVI) as adsorbent. Int. J. Inno. Res. Sci., Eng. Tech., 2, 6140-6149(2013).

Lagergren, S.: About the theory of so-called adsorption of soluble substances. Kungl. Sven. Vetenskapsakad. Handling., 24, 1-39 (1898).

Langmuir, l.: The adsorption of gases on plane surfaces of glass, mica and platinum. J. Am. Chem. Soc., 40, 1362-1403 (1918).

Madhusudhanan, M., S. Badhusha and D. Saranya: Biosorption of chromium from aqueous solution by Chaetomorpha antennina. $J$. Environ. Biol., 40, 742-747 (2019).

Malik, A.: Environmental challenge vis a vis opportunity: The case of water hyacinth. Environ. Int., 33, 122-138 (2007).

Martinez, M., N. Miralles, S. Hidalgo, N. Fiol, I. Villaescusa and J. Poch: Removal of lead (II) and cadmium (II) from aqueous solutions using grape stalkwaste. J. Hazard. Mater.,133, 203-211(2006).

Mckay, G., M. Otterburn and A. Sweeney: The removal of colour from 
effluent using various adsorbents - IV. Silica: Equilibria and column studies. Water Res., 14, 21-27 (1980).

Mohanty, K., M. Jha, B.C. Maikap and M.N. Biswas: Biosorption of Cr(VI) from aqueous solutions by Eichhornia crassipes. Chem. Eng. J., 117, 71-77 (2006).

Murali, S. and M. Rajan: Bioremediation of chloride from tannery effluent (Senkulam Lake in Dindigul Batlagundu highway) with Halobacterium species and bacteria isolated from tannery effluent. Int. J. Environ. Biol., 2, 23-30 (2012).

Newman, D.: A case of Adeno- carcinoma of the left inferior turbinated body, and perforation of the nasal septum, in the person of a worker in chrome pigments. Glasgow Med. J., 33, 469-470 (1890).

Oladoja, N.A. and Y.D. Alice: Snail shell as coagulant aid in the alum precipitation of malachite green from aqua system. J. Hazard. Mater., 164, 1496-1502 (2009).

Peng, K., C. Luo, L. Lou, X. Li and Z. Shen: Bioaccumulation of heavy metals by the aquatic plants Potamogeton pectinatus $\mathrm{L}$. and Potamogeton malaianus Miq. and their potential use for contamination indicators and in wastewater treatment. Sci. Total Environ., 392, 22-29 (2008).

Premalatha, R.P., E. Parameswari, V. Davamani, P. Malarvizhi and S. Avudainayagam: Biosorption of chromium (III) from aqueous solution by water hyacinth biomass. Madras. Agric. J., 106,12-21 (2019).

Puentes Cardenas, P.A.M., J.G. Ibanez and M.R. Vasquez: Determination of point of zero charge for electrocoagulation precipitates from an iron anode. Int. J. Electrochem. Sci., 7, 6142$6153(2012)$.

Rajeswari, T.R. and N. Sailaja: Impact of heavy metals on environmental pollution. J. Chem. Pharm. Sci., 3,175-181 (2014).
Saha, P., O. Shinde and S. Supriya: Phytoremediation of industrial mines wastewater using water hyacinth. Int. J. Phytorem., 19, 87-96 (2017).

Salehzadeh, J.: Removal of heavy metals $\mathrm{Pb}^{2+}, \mathrm{Cu}^{2+}, \mathrm{Zn}^{2+}, \mathrm{Cd}^{2+}, \mathrm{Ni}^{2+}, \mathrm{Co}^{2+}$ and $\mathrm{Fe}^{3+}$ from aqueous solutions by using Xanthium pensylvanicum. Leonardo. J. Sci., 23, 97-104 (2013).

Sebastian, S.P., C.Udayasoorian, R.M. Jayabalakrishnan and E. Paramesewari: Improving soil microbial biomass and enzyme activities by amendments under poor quality irrigation water. World Appl. Sci. J., 7, 885-890 (2009).

Singh, S., A. Tripathi and S.K. Srivastava: Comparative biosorption competencies of Ficus, Syzygium and Mangifera seeds for hexavalent chromium mitigation from polluted water. J. Environ. Biol., 39, 159-165 (2018).

Tarley, C.R.T. and M.A.Z. Arruda: Biosorption of heavy metals using rice milling by products. Characterizations and application for removal of metals from aqueous effluents. Chemosphere, 54, 987-995 (2004).

Tempkin, M.I. and V. Pyzhev: Kinetics of ammonia synthesis on promoted iron catalyst. Acta Physicochimica U.R.S.S., 12, 327356 (1940).

Uddin, N., T. Islam and S. Dos: A novel biosorbent, water hyacinth, uptaking methylene blue from aqueous solution: Kinetics and equilibrium studies. Int. J. Chem. Eng., 2014, 1-13 (2014).

Varank, G., A. Demir, K. Yetilmezsoy, S. Top, E. Sekman and M.S. Bilgili: Removal of 4- nitrophenol from aqueous solution by natural low costadsorbents. Indian J. Chem. Technol.,19, 7-25 (2012).

Xu, D., X.L. Tan, C.L., Chen and X.K. Wang: Adsorption of Pb(II) from aqueous solution to $\mathrm{MX}-80$ bentonite: effect of $\mathrm{pH}$, ionic strength, foreign ions and temperature. Appl. Clay. Sci., 41, 37-46 (2008). 